\title{
The Effect of Core Vocabulary Extension Program for Children with Inconsistent SSD
}

\author{
Yoo-Kyeong Ko ${ }^{a}$, Soo-Jin Kim ${ }^{\mathrm{b}}$ \\ ${ }^{a}$ Barunsori Speech, Language \& Learning Clinic, Jeju, Korea \\ ${ }^{b}$ Department of Speech-Language Pathology, Nazarene University, Cheon-an, Korea
}

Correspondence: Soo-Jin Kim, PhD

Department of Communication Disorders, Korea Nazarene University, 48 Wolbong-ro, Seobuk-gu, Cheonan 31172, Korea

Tel: $+82-41-570-7978$

Fax: $+82-41-570-7846$

E-mail: sjkim@kornu.ac.kr

Received: July 5, 2021

Revised: August 8, 2021

Accepted: August 23, 2021

This thesis is an abbreviated version of the first author's doctoral thesis.
Objectives: The purpose of this study was to determine the effect of the Core Vocabulary Extension Program for establishing speech sound consistency on speech inconsistency and accuracy of children with inconsistent SSD. Methods: Four children with inconsistent SSD aged 3-5 years who exhibited speech sound inconsistency, phonological error patterns, and articulation problems at the same time participated in this study. The program of this study used a core vocabulary approach and a multi-sensory approach, and parental support was provided the same time. The experimental design used a multiple probe baseline design, with 3-5 baseline evaluations, 10 treatment evaluations, and 3 maintenance evaluations were performed. Data analysis of dependent variables, mean, trend line slope, standard deviation, immediate effect of treatment, and ratio of non-overlapping data (PND) were analyzed. Results: As a result of the study, inconsistency was reduced and articulation ability was improved. Speech inconsistency improvement was effective in all four participating children, but accuracy improvement was only effective in three children. Conclusion: This study is significant in that it confirmed the therapeutic effect of the Core Vocabulary Extension Program which integrated a multisensory approach and parent coaching based on a core vocabulary approach on speech sound inconsistency and accuracy of children with severe speech sound disorder accompanied by intellectual problems and language disorders. In the future, it is necessary to apply a phonological approach to remove the remaining phonological error patterns after speech consistency is established and to confirm the effectiveness of the phonological approach

Keywords: Inconsistency, Core-vocabulary approach, Multi-sensory approach, Inconsistent SSD (speech sound disorders)
말소리장애는 말 산출 문제로 인해 의사소통의 어려움을 보이는 경우로, 말소리 오류유형, 말소리 문제의 중증도, 장애의 기저 원인 및 다른 장애동반 유무에 따라 복합적이고 다양한 문제를 가진다 (Dodd, 2005). 아동이 보이는 말소리 문제는 조음방법과 조음위치 에서 오류를 보이는 조음오류의 문제, 특정 문맥에서 공통적으로 보이는 음운오류패턴 문제도 있지만, 비일관되게 오류를 보이는 비 일관성 문제도 있다(Shriberg et al., 2017). 원인을 모르는 말소리장 애의 경우 다른 의사소통 영역의 문제가 없이 말소리 문제만 보이 는 경우도 있지만, 조음과 음운오류패턴 및 비일관성 등 말소리 문 제를 복합적으로 보이는 심각한 경우에는 언어장애나 지적장애와
같은 다른 장애를 동반한 경우가 많다(Dodd, 2005; Shriberg \& Austin, 1998).

말소리장애의 보다 효과적인 치료법을 찾기 위해서, 조음과 음운 오류패턴 및 비일관성을 기반으로 Dodd, Zhu, Crosbie, Holm과 Ozanne (2006)은 네 개의 집단 즉, 조음장애, 음운지연, 일관성 음 운장애, 비일관성 음운장애로 분류하였다. 증상을 기반으로 분류 한 네 개의 하위집단 중 비일관성 말소리장애로 진단받은 아동은 나타나는 오류가 음운패턴 또는 규칙으로 설명하기 어려워 다른 하위집단보다 치료목표를 계획하는데 어려움을 가지고 있으며 $(\mathrm{Ha}$ \& Seo, 2019), 치료기간이 가장 길고, 복잡하고 다양한 말 문제를 
가지며, 언어장애, 지적장애 동반 위험도 가장 높았다(Lewis et al., 2015). 말소리장애 아동의 증상별 하위분류에 따라 다른 특징이 존 재할 뿐만 아니라, 증상에 따라서 하위집단으로 분류한 이유는 각 각의 집단에 효과적인 치료접근법이 다르기 때문이다(Dodd \& Bradford, 2000).

비일관성 음운장애로 분류된 아동은 비일관성 문제를 보일 뿐 아니라 중등도 이상의 말소리 오류와 함께, 언어장애를 동반하는 경우가 많은 것으로 알려져 있다(Dodd, 2005; Shriberg \& Austin, 1998). 말소리장애 아동의 언어 문제는 치료적 접근을 결정하는 데 매우 중요한 요인이 될 수 있다. 원인을 모르는 말소리장애 아동 중 절반 이상이 언어장애를 동반하였다(Kim, $\mathrm{Kim}, \mathrm{Ha}, \& \mathrm{Ha}, 2015$; Ko, Seo, Oh, \& Kim, 2017; Shriberg, Tomblin, \& McSweeny, 1999). 특히 말소리 비일관성 오류가 심각할수록 더 낮은 언어 점수를 나 타냈다(Lewis et al., 2012). 표현언어 사용이 서툰 아동은 단어를 산 출할 때 발음되는 방식에 따라 언어표현에 대한 부담을 갖게 되는 데, 이러한 부담감은 말소리 일관성 산출에 영향을 끼치기도 한다 (Dodd, Leahy, \& Hambly, 1989). 언어표현에 대한 부담으로 사용 하는 단어에서 일관되지 않은 다양한 음운오류패턴이 산출되어 비 일관성 음운오류를 나타내는 경우가 많아진다(Dodd, 2005). 언어 장애를 동반하고 비일관성 음운장애로 진단된 심각한 말소리장애 아동은 말언어 문제뿐만 아니라 학령기 이후에도 문해력을 비롯 한 다양한 언어학습 측면에서 어려움을 초래할 수 있다(Paul, 1993).

심한 말소리장애 아동은 말소리 비일관성 오류를 보이는 경우가 많으며, 말소리 비일관성 오류는 기저에서 언어-인지적인 부분에 어려움을 보이는 것으로 의심되는 증상 중 하나이므로, 효과적인 치료접근 전략은 단어 전체에 초점을 두고 접근할 것을 추천하고 있다(Dodd \& Bradford, 2000). 말소리 비일관성 오류를 보이는 심 한 말소리장애 아동은 단어를 구성하는 음소의 순서를 계획하는 능력이 취약하기 때문에(Ferguson \& Farwell, 1975), 전체 단어를 연습하는 핵심어휘접근법(Core Vocabulary Approach)을 우선 적 용하는 것이 효과적이다(Bradford, 1996; Broomfield \& Dodd, 2005; Crosbie, Holm, \& Dodd, 2005; Dodd \& Bradford, 2000; Dodd \& Iacono, 1989; Herman et al., 2015; McIntosh \& Dodd, 2008). 국내에서도 말소리장애 아동의 하위집단별 차별적 치료가 필요하다는 점이 강조되고 있으나, 말소리 일관성 확립에 대한 핵심 어휘접근법의 치료효과를 확인하거나 비일관성을 치료하고 객관 적으로 검증한 연구는 아직 발표된 바 없다. 핵심어휘접근법의 치 료목표는 아동이 산출 가능한 '최상의 산출' 형태로 일상의 고빈도 어휘 50 여 개에서 일관성을 확립하는 것이다. 말소리 일관성이 확 립된 단어가 50 개 이상으로 확장되면, 전체 단어에서 부분 음운체
계로의 재구성이 가능해지기 때문이다(Ferguson \& Farwell, 1975). 핵심어휘접근법 단독으로 말소리치료가 완성될 수는 없으며, 50 개 이상의 어휘에서 일관된 산출이 가능해지면 다른 음운적 접근법을 적용해야 한다고 하였다. 특히 핵심어휘접근법의 회기 수를 계획하 는 데 있어 심각도와 교사 및 양육자의 의견에 따라 다르지만, 핵심 어휘접근법만으로는 16 회기가 가장 적절하며, 16 시간 30 분을 초과 하지 않도록 할 것을 추천하고 있다. 이렇게 시간을 제한하는 이유 중 하나는 현재 아동이 산출한 ‘최상의 산출’이 정조음일 수도 있지 만 오조음인 경우, 오조음이 지나치게 강화되는 것을 경계하기 위 한 것이다. 핵심어휘접근의 초기 접근에서는 우선 최상의 산출 형태 가 최선이 될 수 있도록 하는 보완책이 필요할 수 있다고 하겠다.

심한 말소리장애 아동은 언어-인지적 부분에서만이 아니고 운 동 차원에서의 조음 문제를 보이는 경우도 많다(Pieretti, Kaul, Zarchy, \& O'Hanlon, 2015). 특히 조음위치를 찾지 못하는 문제를 보이는 경우는 개별 말소리의 움직임에 초점을 맞춘 음성접근법이 가장 효과적(Weiss, Gordon, \& Lillywhite, 1987)인 것으로 알려져 있다. 음성접근법 중에서 다중감각접근법(Multi-Sensory Appro$\mathrm{ach})$ 은 청각, 시각, 촉각 감각 정보를 모두 통합하여 사용하기 때문 에 다양한 감각자극을 필요로 하는 심한 말소리장애 아동의 조음 확립을 위한 적절한 접근법이라고 할 수 있다(Square, Namasivayam, Bose, Goshulak, \& Hayden, 2014). 다중감각접근법은 정확한 조음위치를 확인하여 조음명료도를 높이는 데는 효과적이지만 (Lee, 2018; Rogers et al., 2006; Square, Goshulak, Bose, \& Hayden, 2000), 단독으로 사용하는 것보다 말 산출을 위한 다른 접근법들 과 절충하여 사용하는 것이 더 큰 효과를 얻을 수 있다. 많은 임상 가와 연구자들은 말소리산출 문제를 가진 심한 말소리장애 아동에 게 다중감각접근법을 다른 접근법과 절충하여 사용한다면 조음확 립에 큰 치료효과를 얻을 수 있다고 제안하고 있다(Pieretti et al., 2015).

말소리장애 아동을 위한 효과적인 것으로 확인된 치료법(Hayden, 2004; Herman et al., 2015; Hesketh, Nightingale, \& Hall, 2000)들 의 대부분은 반복연습을 강조하는 방법들로, 획득한 말소리 일관 성과 음운체계의 완전한 확립을 위해서는 치료실 상황뿐만 아니라, 가정 등 일상적인 상황에서 반복적으로 연습해야 한다는 점을 강 조하고 있다(Gunther \& Hautvast, 2010; Lancaster, Keusch, Levin, Pring, \& Martin, 2010). 특히, 말소리 일관성 확립을 목표로 하는 핵심어휘접근법의 치료에 있어 목표 단어를 가정에서 매일 연습할 수 있도록 확인하는 부모역할이 중요하므로(Broomfiled \& Dodd, 2005; Dodd, 2005), 부모코칭 후 부모지원을 절충하여 사용한다면 보다 효과적인 치료 결과를 얻을 수 있다. 
본 연구의 목적은 말소리산출에 있어서 일관성과 정확성이 모두 떨어지는 비일관성 말소리장애 아동을 대상으로 '핵심어휘 확장 프로그램'을 개발하고, 그 효과를 알아보는데 있다. '핵심어휘 확장 프로그램'은 초기 4 회기 동안 집중적인 다중감각접근법을 적용하 여 ‘최상의 산출'을 유도하고, 다음 16 회기 동안 핵심어휘접근과 부 모코칭을 병행하는 것이다. 치료 프로그램의 효과는 중다간헐기초 선설계를 통해 말소리의 비일관성과 조음 정확성이 개선되었는지 검증하고자 한다.

\section{연구방법}

\section{연구대상}

본 연구의 대상은 표준화 검사에서 자음정확도(PCC)가 $65 \%$ 이 하인 중심도 말소리장애에 해당되며, 감각, 신체, 정서, 신경학적, 조 음기관의 구조 및 기능적 결함이 없으며, 언어 및 말소리장애 치료 를 받은 이력이 없는 아동들 중 말소리 비일관성, 음운오류패턴, 조 음 문제를 동시에 보이는 3-5세의 말소리장애 아동으로 선정하였 다. 연구 대상자의 자음목록과 말소리 비일관성은 PCC 평가를 위 한 표준화 검사의 단어로 3 회씩 더 산출하도록 하여 평가하였다. 말 소리 비일관성은 단어수준 검사와 단어 검사의 목표단어가 포함된 문장수준 검사를 제작한 후, 단어 명명하기-문장 따라말하기-단어 명명하기 순서로 진행하였다. 본 연구의 대상자와 비슷한 증상을 보이는 아동기 말실행증(Childhood Apraxia Speech, CAS)을 배제 하기 위해, CAS 감별진단 표지인 '모색행동, '말소리를 모방하지 못 함', '운율 문제', ‘조음 길항운동 과제 어려움'Forrest, 2003; Lawrence et al., 2003; Schmidt \& Lee, 1999; Shriberg, Austin, Lewis, McSweeny, \& Wilson, 1997)을 보이지 않는 아동으로 선정하였다. 연구 대상자의 특성은 Table 1과 같다. 표준화검사를 실시한 결과, 네 아동 모두 말소리장애로 진단되었으며, 세 명은 어휘검사에서 백분위 10 미만이고, 그중 두 명은 비언어지능검사에서 백분위 17 이하이다.

\section{치료 프로그램}

핵심어휘 확장 프로그램의 치료회기는 총 20 회기로 계획하였으 며, 구체적인 내용 및 절차는 Appendix 1에 제시하였다. 최초 4회기 는 다중감각자극을 통해 아동이 가지고 있는 음운체계 및 음운목 록을 기반으로 '최상의 산출' 방법을 확인하고 유도하였다. Lee (2018)의 연구를 참고하여, 다중감각접근법의 절차 중 조음장소의 다음 이동으로의 신호전환을 촉진하기 위해 촉각, 시각, 청각자극 을 동시에 제공하는 Surface PROMPT와 손 자극을 시각 단서로 보 여주는 Air PROMPT를 도입 적용하였다. 다음 16회기는 Dodd (2005)의 핵심어휘치료접근법을 참고한 치료법을 적용하였다. 핵심 어휘훈련 기간에는 1 차로 확립한 '최상의 산출'로 단어, 구조화된 문장, 상황 맥락에서 말소리 일관성을 유지하는 것을 목표로 하였 다. 치료사와 부모는 정조음 산출에 대한 요구나 피드백을 제공하 지 않고, 최상의 산출 형태만 일관되게 산출하는 것을 목표로 하였 다. 모든 회기의 언어치료 수행 직후에 부모코칭을 10 분씩 진행하 였다. 부모코칭 방법은 보호자와 아동이 집에서 직전 회기 과제를 연습하도록 하고, 부모코칭을 받은 내용을 1 일당 15 분씩 주 4 회 가 정지도를 시행하여 연습 과정 중 5 분간의 아동 음성 샘플을 녹음 한 후 연구자에게 전송하도록 하였다. 연구자는 전송된 녹음파일 을 듣고 연습에 대한 피드백을 제공하였다.

\section{평가절차}

치료의 효과를 확인하기 위해 대상자 간 중다간헐기초선실험설 계를 사용하였다. 사전검사, 기초선단계, 치료단계, 유지평가는 모 두 동일한 장소인 사설치료센터에서 일대일 상황으로 진행하였다.

모든 연구대상자의 기초선 자료가 일정 수준에서 안정세를 보일 때 첫 번째 대상자의 치료를 시작하며, 첫 번째 대상자의 치료효과 가 보이기 시작할 때, 두 번째 대상자에게 동일한 과정의 치료를 적 용하였다. 이와 동일한 절차에 따라 나머지 대상자에 대한 치료를 적용하였다. 유지 효과는 중재 종료일부터 7일 후에 주 1 회씩 3 주간 3 회기 실시하였다.

Table 1. Participants' Characteristic

\begin{tabular}{lcccccccc}
\hline Participant & Gender & Age (yr;mo) & PCC & Consonant inventory & Inconsistency frequency & REVT-R & REVT-E & K-CPM \\
\hline C1 & M & $3 ; 7$ & $41.4 \%$ & 16 & $40.5 \%$ & $<10 \%$ ile & $<10 \%$ ile & $75 \%$ ile \\
C2 & M & $4 ; 10$ & $64.3 \%$ & 18 & $40.5 \%$ & $20-30 \%$ ile & $30-40 \%$ ile & $92 \%$ ile \\
C3 & M & $3 ; 10$ & $32.9 \%$ & 14 & $62.2 \%$ & $<10 \%$ ile & $<10 \%$ ile & $16 \%$ ile \\
C4 & F & $4 ; 0$ & $24.3 \%$ & 11 & $67.6 \%$ & $<10 \%$ ile & $<10 \%$ ile & $17 \%$ ile \\
\hline
\end{tabular}

PCC = Assessment of Phonology \& Articulation for Children; APAC=Assessment of Phonology \& Articulation for Children (Kim, Pae, \& Park, 2007); Consonant Inventory= The number of consonants 18 initial Consonants \& 7 final Consonants; Inconsistency frequency=Measured by repeating the APAC test word 3 times; REVT=Receptive \& Expressive Vocabulary Test (Kim, Hong, Kim, Jang, \& Lee, 2009); K-CPM= Korean-Coloured Progressive Matrices (Lim, 2004). 
평가단어는 각 아동별로 10 개씩 선정하였다. 아동별로 비일관되 게 산출하는 일상 생활에서의 고빈도 어휘를 치료 프로그램 시작 전에 60 개씩 수집하였고, 60 개 중 50 개는 치료 목표단어로 하고 10 개는 평가단어로 정하였다. 선정된 60 개 단어들을 고빈도 순으로 일련번호를 매기고 나열한 후, 일련번호 6 의 배수에 해당되는 단어 들을 평가단어로 선정하고, 나머지 단어들은 목표단어로 선정하였 다. 따라서 치료단어와 평가단어는 대상 아동별로 모두 다르다. 기 초선, 치료, 유지단계 모두 10 개 평가단어를 4 회씩 산출하도록 유도 하여 일관성과 정확성을 평가하였다. 기초선은 아동에 따라서 3-5 회, 유지단계는 3 회씩 평가하였고, 치료단계는 20 회기 중 짝수 회기 에만 평가하였으므로 총 10 회씩 평가하였다.

\section{자료분석}

말소리 비일관성은 Ingram (2002)의 단어단위변화율(Proportion of Wole-word Variation, PWV) 측정법을 사용하여 치료의 짝 수 회기 및 기초선-유지 회기마다 검사단어를 언어적 단위에 따라 산출하도록 하여 측정하였다. PWV의 채점 방식은 아동이 4 회 산 출한 단어를 한글로 전사한 후 말소리 비일관성 여부를 표시하고, 말소리 비일관성의 범주 및 횟수와 상관없이 비일관성을 나타낸 단 어 당 1 점을 부과하여 비율을 계산한다. $\mathrm{PWV}$ 는 산출단어 중 서로 다르게 산출한 단어의 유형수를 산출단어의 수로 나눈 후 100 을 곱하여 산출한다. $\mathrm{PWV}$ 의 채점 방식은 비일관성 말소리장애를 감 별하기 위해 개발된 조음음운진단(DEAP; Dodd, Crosbie, Zhu, Holm, \& Ozanne, 2002)의 하위 검사 중 말소리 비일관성 검사에서 계산하는 방식과 동일하다.

Percentage of Correct Consonant (PCC)와 Proportion of Whole-word Correctness (PWC)는 비일관성 측정을 위해 4회씩 반복하여 산출한 단어를 평균하여 산출하였다. PWC의 채점은 아 동이 산출한 단어 중 정조음으로 산출한 단어는 1 점으로 계산하 고, 부정확하게 산출된 단어는 0 점으로 계산한다.

치료 결과의 근거 강도를 높이기 위해 What Works Clearinghouse (WWC; Kratochwill et al., 2010) 평가 기준에 근거하여 PWV, PCC, $\mathrm{PWC}$ 의 평균(level), 경향선 기울기(trend), 표준편차(variability)를 분석하였다. 또한, 치료의 효과를 입증하기 위해 즉시성효과(immediacy of the effect), 비중복정도(overlap; PND)의 비율을 분석 하였다. 즉시성효과는 치료 후 바로 변화하는 수준을 반영하는 지 표로, 기초선 마지막 3 회기 평균값과 치료회기의 명백하게 다른 지 점의 값을 비교한다. $\mathrm{PND}$ 는 치료기간 중 기초선 종속치의 최고점 과 비교해서 점수가 높은 치료회기 수를 합산한 후, 전체 치료회기 수로 나눈 후에 100 을 곱하여 구했다.
Table 2. Inter-assessor reliability

\begin{tabular}{lcccc}
\hline \multirow{2}{*}{ Division } & \multicolumn{4}{c}{ Reliability } \\
\cline { 2 - 5 } & Baseline & Treatment & Maintain & Total \\
\hline Speech sound inconsistency & & 100 & 93.5 \\
M (\%) & 86.9 & 93.75 & 100 & $80.0-100$ \\
Range (\%) & $80.0-100$ & $87.5-100$ & & \\
PCC & & & 94.7 & 96.3 \\
M (\%) & 95.8 & 98.3 & $92.1-100$ & $80.0-100$ \\
Range (\%) & $80.0-100$ & $96.1-98.6$ & & \\
\hline
\end{tabular}

\section{평가자 간 신뢰도}

본 연구의 목적에 대해 모르는 1 명의 평가자와 제 1 연구자가 전사 한 전체 자료 중 각 연구 참여자의 기초선, 치료, 유지 수준의 전체 20.3\%에 해당되는 녹음자료를 무작위로 선택하여 평가자 간 신뢰 도를 산출하였다. 두 평가자에 의해 기록된 PWV, PCC를 계산하 여 일치하는지 확인하였다. 연구자와 평가자는 모두 언어치료 경력 이 10 년 이상으로, 1 급 언어재활사 자격을 소지하고 있으며, 말소리 장애에 대해 연구를 한 전문가였다. 두 평가자 간 각 참여 아동에 대한 PWV 및 PCC에 대한 신뢰도는 Table 2와 같다.

\section{치료 충실도}

본 연구의 치료에 참여한 연구자와 연구보조자의 치료 충실도를 알아보기 위해 체크리스트를 사용하여 각 연구 참여 아동별 3회씩 으로 전체 치료회기의 $15 \%$ 에 해당하는 총 12 회기에 대해 실시하였 다. 치료 충실도를 확인하기 위해 연구자와 연구보조자는 매 회기 치료마다 5 분간 동영상 촬영을 하였고, 이 중 12 회기의 동영상 자료 를 무작위로 선정하여 치료 충실도를 평가하였다. 치료 충실도는 언어치료경력 7 년에 1 급 언어재활사 자격을 가지고 있는 언어재활 사가 촬영된 동영상을 보고 각 항목에 대한 수행 여부를 기록하였 다. 치료 충실도 평가 결과, 전체 평균 $94.0 \%$ (범위 $=84.2-100 \%$ )로 평가되었다.

\section{연구결과}

\section{말소리 비일관성}

말소리 비일관성 변화는 PWV로 살펴보았는데, 참가자별 PWV 는 Table 3, Figure 1과 같다. 네 아동 모두 말소리 비일관성은 크게 감소하였다. 기초선 평균은 $90.00 \%$ 이었으나, 치료가 끝난 유지기간 의 PWV 평균은 $35.00 \%$ 로 낮아졌다. 즉시성효과는 개인별로 차이 를 나타냈으나, PND 비율은 네 아동 모두에서 치료효과를 보인 것 으로 나타났다. C4 아동은 매우 효과적인 것으로 나타났으며, C1 
Table 3. Speech inconsistency data from participants C1-C4

\begin{tabular}{|c|c|c|c|c|c|c|c|}
\hline Session & Participant & $\mathrm{M}(\%)$ & Range (\%) & Variability & Trend & Immediacy of effect (\%) & PND (\%) \\
\hline \multirow[t]{4}{*}{ Baseline } & $\mathrm{C1}$ & 70.00 & 70 & .00 & .00 & - & - \\
\hline & C2 & 90.00 & 90 & .00 & .00 & - & - \\
\hline & C3 & 100.00 & 100 & .00 & .00 & - & - \\
\hline & C4 & 92.00 & $90-100$ & 4.00 & -2.50 & - & - \\
\hline \multirow[t]{4}{*}{ Intervention } & C1 & 55.00 & $30-70$ & 13.60 & -3.33 & 6.67 & 70.00 \\
\hline & C2 & 72.00 & $30-90$ & 19.39 & -6.67 & 0.00 & 60.00 \\
\hline & C3 & 75.00 & $50-100$ & 18.03 & -5.56 & 3.33 & 80.00 \\
\hline & C4 & 58.00 & $30-80$ & 18.87 & -5.56 & 16.67 & 100.00 \\
\hline \multirow[t]{4}{*}{ Maintenance } & $\mathrm{C1}$ & 23.30 & $10-30$ & 9.42 & .00 & - & - \\
\hline & C2 & 36.37 & $30-40$ & 4.71 & .00 & - & - \\
\hline & C3 & 46.67 & $40-50$ & 4.71 & 5.00 & - & - \\
\hline & C4 & 33.33 & $30-40$ & 4.71 & .00 & - & - \\
\hline
\end{tabular}

Values are presented as mean.

Range=Range of frequencies of speech inconsistency; Variability=Standard deviation; Trend=Slope of the best-fitting straight line for the data within a phase; PND = Percentage of Nonoverlapping Data; Low intervention effect (yellow color); Moderate intervention effect (green color); Very effective intervention (red color).

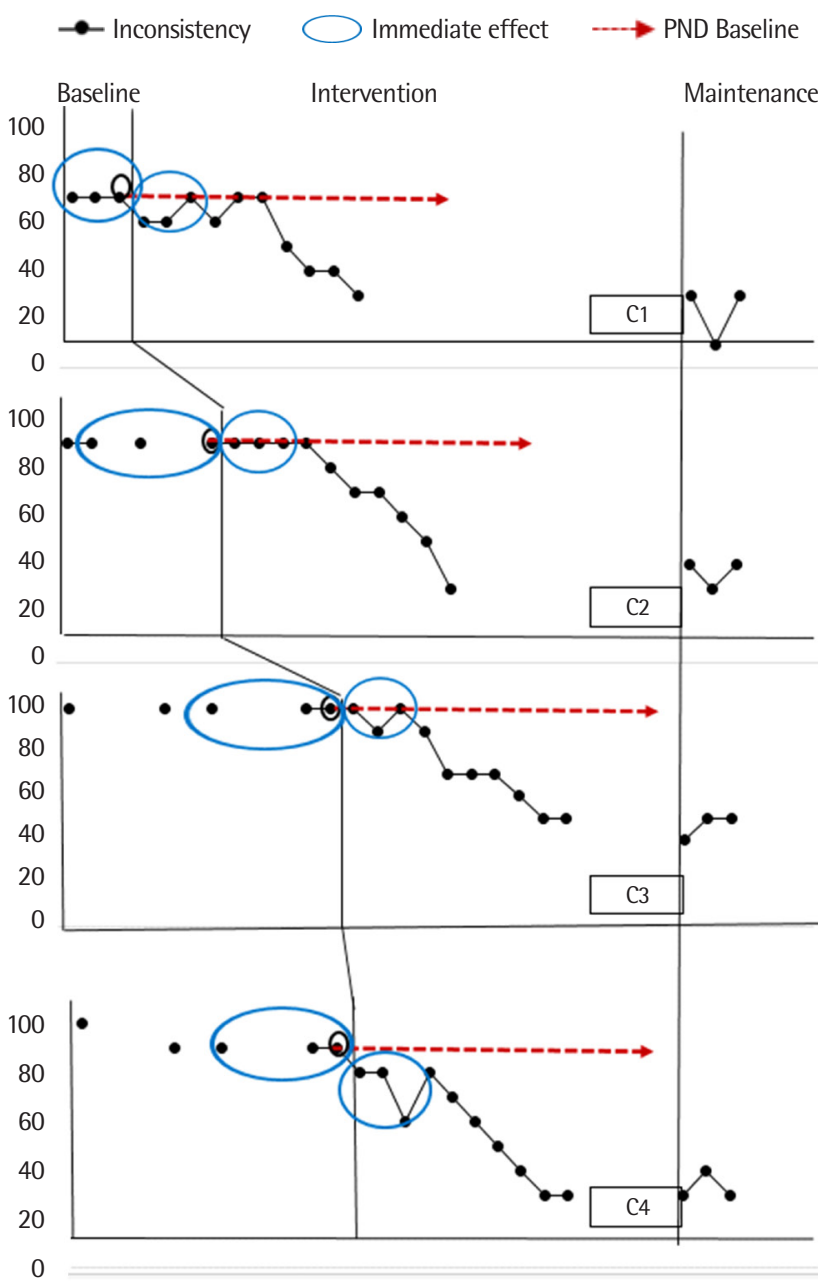

Figure 1. Speech inconsistency data from participants C1-C4. PND=Percentage of Nonoverlapping Data.
과 $\mathrm{C} 3$ 아동은 중간 정도의 효과를 나타냈고 $\mathrm{C} 2$ 아동은 낮은 치료 효과를 보였다. 유지기간에도 안정된 경향선 기울기로 치료기간 동 안 확립된 말소리 일관성이 유지되는 것으로 나타났다.

\section{말소리 정확성}

말소리의 정확성은 자음정확도(PCC)와 단어단위정확률(PWC) 로 변화추이를 분석하였다.

\section{자음정확도(PCC)}

참가자별 PCC 변화는 Table 4와 Figure 2에 제시하였다. 네 아동 의 PCC 기초선 평균은 $37.00 \%$ 였으며, 치료가 끝난 유지기간의 평 균은 $62.90 \%$ 로 증가하였다. PCC는 개인별로 증가되는 시기와 증 가폭이 상이하였다. C2 아동은 치료 중반에 크게 상승되었고, $\mathrm{C} 1$ 아동과 C4 아동은 치료 후반에 큰 상승세를 보였다. C3 아동의 PCC는 큰 변화를 보이지 않았다. 즉시성효과는 C4 아동은 매우 효과적인 것으로 나타났으며, $\mathrm{C} 2$ 아동은 중간 정도의 효과, $\mathrm{C} 1$ 과 $\mathrm{C} 2$ 아동은 낮은 효과를 보였다.

\section{단어단위정확률(PWC)}

개인별 PWC는 Table 5와 Figure 3에 제시하였다. 네 아동의 기초 선 평균은 .08이었으나, 치료가 끝난 유지기간의 PWC 평균은 .26 으로 증가하였다. C3 아동을 제외한 세 아동은 치료과정 동안 향 상되었다. 참여 아동들의 즉시성효과는 크지 않았으며, $\mathrm{PND}$ 비율 로 확인한 치료효과는 C3 아동을 제외한 모든 아동이 효과를 나 타냈다. C4 아동은 매우 효과적인 것으로 나타났으며, C1과 C2 아 
Yoo-Kyeong Ko, et al. • Effect of Speech Sound Inconsistency Treatment

Table 4. PCC data from participants C1-C4

\begin{tabular}{|c|c|c|c|c|c|c|c|}
\hline Session & Participant & $\mathrm{M}(\%)$ & Range (\%) & Variability & Trend & Immediacy of effect (\%) & PND (\%) \\
\hline \multirow[t]{4}{*}{ Baseline } & $\mathrm{C} 1$ & 27.33 & $24-32$ & 3.39 & -4.00 & - & - \\
\hline & $\mathrm{C} 2$ & 64.50 & $60-67$ & 2.69 & .67 & - & - \\
\hline & C3 & 33.40 & $28-40$ & 4.45 & 1.75 & - & - \\
\hline & C4 & 24.40 & $22-28$ & 2.33 & 1.00 & - & - \\
\hline \multirow[t]{4}{*}{ Intervention } & C1 & 33.50 & $24-45$ & 7.13 & 1.56 & $\nabla 3.33$ & 60.00 \\
\hline & $\mathrm{C} 2$ & 78.30 & $63-91$ & 10.75 & 3.11 & 2.00 & 70.00 \\
\hline & C3 & 38.70 & $33-48$ & 4.36 & .78 & 0.33 & 50.00 \\
\hline & C4 & 43.50 & $27-71$ & 12.77 & 4.67 & 9.00 & 90.00 \\
\hline \multirow[t]{4}{*}{ Maintenance } & $\mathrm{C1}$ & 40.67 & $38-44$ & 2.49 & 3.00 & - & - \\
\hline & $\mathrm{C} 2$ & 87.33 & $81-93$ & 4.92 & 6.00 & - & - \\
\hline & C3 & 46.00 & $44-47$ & 1.14 & .00 & - & - \\
\hline & C4 & 69.67 & $68-72$ & 1.69 & -.50 & - & - \\
\hline
\end{tabular}

Values are presented as mean.

Range $=$ Range of frequencies of speech inconsistency; Variability=Standard deviation; Trend=Slope of the best-fitting straight line for the data within a phase; PND=Percentage of Nonoverlapping Data; Low intervention effect (yellow color); Moderate intervention effect (green color); Very effective intervention (red color).

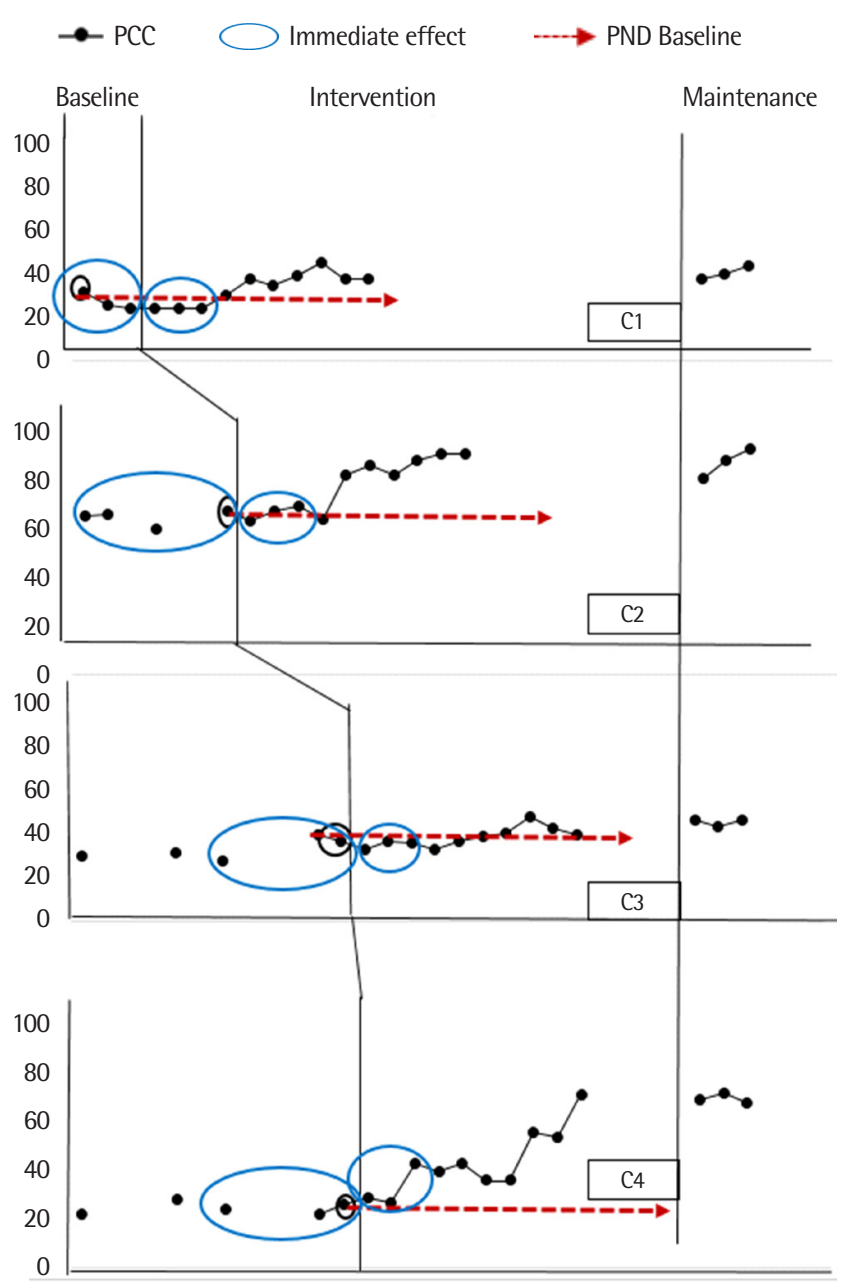

Figure 2. PCC data from participants C1-C4.

$\mathrm{PCC}=$ Percentage of Correct Consonant; $\mathrm{PND}=$ Percentage of Nonoverlapping Data.
동은 중간 정도의 효과를 보였다.

\section{논의 및 결론}

말소리 오류가 심각하면서 비일관성 문제를 동시에 보이는 아동 에게는 우선 일관성을 확립한 뒤에 정확성을 높이는 접근이 보다 효율적인 것으로 알려져 있다. 말소리 비일관성을 줄이기 위해 현재 까지 소개된 치료법 중 가장 효율적인 방법이라고 알려진 핵심어휘 접근법을 적용한 근거기반 연구들이 필요하다(Dodd \& Bradford, 2000; Herman et al., 2015). 본 연구는 핵심어휘접근법의 효과를 극 대화하기 위하여 다중감각접근법과 부모코칭을 접목한 치료 프로 그램을 개발하고, 네 명의 비일관성 말소리장애 아동에게 적용한 뒤 그 효과를 객관적으로 확인하고자 하였다.

치료 프로그램 적용 효과는 말소리 비일관성과 정확성의 개선이 라는 두 가지 측면에서 살펴보았다. PWV로 평가한 비일관성은 기 초선단계와 치료단계의 PND 비율이 60-100\%로 네 명 모두 개선되 었음을 보여주었다. PCC와 PWC로 평가한 정확성은 기초선기간 동안 평가단어를 말소리 비일관성으로 산출하여 $\mathrm{PCC}$ 와 PWC에 서도 안정된 기울기를 나타내지는 않았으나, PND 비율 $60 \%$ 이상 을 기준으로 본다면 세 명의 아동이 개선되었다. 치료기간 동안 확 립된 말소리 일관성과 정확성은 종료된 유지기간에도 지속되었다. 일반적으로 임상에서 비일관성으로 하위집단을 분류할 때, Dodd (2005)의 분류기준에 근거하여 산출단어의 $40 \%$ 에서 비일관성을 보이는지에 따라 분류하고 있다. 네 아동은 모두 치료 전에는 음운 오류가 ‘비일관된 음운장애집단’으로 분류되었으나, 치료 이후에 는 비일관성 비율이 급격하게 감소하여, ‘일관된 음운장애집단'으 
Table 5. PWC data from participants C1-C4

\begin{tabular}{|c|c|c|c|c|c|c|c|}
\hline Session & Participant & $\mathrm{M}$ & Range & Variability & Trend & Immediacy of effect & PND (\%) \\
\hline \multirow[t]{4}{*}{ Baseline } & $\mathrm{C1}$ & .00 & .00 & .00 & .00 & - & - \\
\hline & C2 & .20 & $.23-.28$ & .10 & -.09 & - & - \\
\hline & C3 & .00 & .00 & .00 & .00 & - & - \\
\hline & C4 & .08 & $.05-10$ & .02 & .01 & - & - \\
\hline \multirow[t]{4}{*}{ Intervention } & $\mathrm{C} 1$ & .10 & $.00-.10$ & .07 & .01 & .08 & 80.00 \\
\hline & C2 & .46 & $.20-.73$ & .20 & .03 & .08 & 70.00 \\
\hline & C3 & .00 & .00 & .00 & .00 & .00 & 0.00 \\
\hline & C4 & .18 & $.15-.30$ & .05 & .01 & .08 & 100.00 \\
\hline \multirow[t]{4}{*}{ Maintenance } & C1 & .10 & .10 & .00 & .00 & - & - \\
\hline & C2 & .68 & $.53-83$ & .12 & .15 & - & - \\
\hline & C3 & .03 & $.00-.05$ & .02 & .00 & - & - \\
\hline & C4 & .26 & $.18-.33$ & .06 & -.09 & - & - \\
\hline
\end{tabular}

Values are presented as mean.

Range = Range of frequencies of speech inconsistency; Variability=Standard deviation; Trend=Slope of the best-fitting straight line for the data within a phase; PND=Percentage of Nonoverlapping Data; Low intervention effect (yellow color); Moderate intervention effect (green color); Very effective intervention (red color).

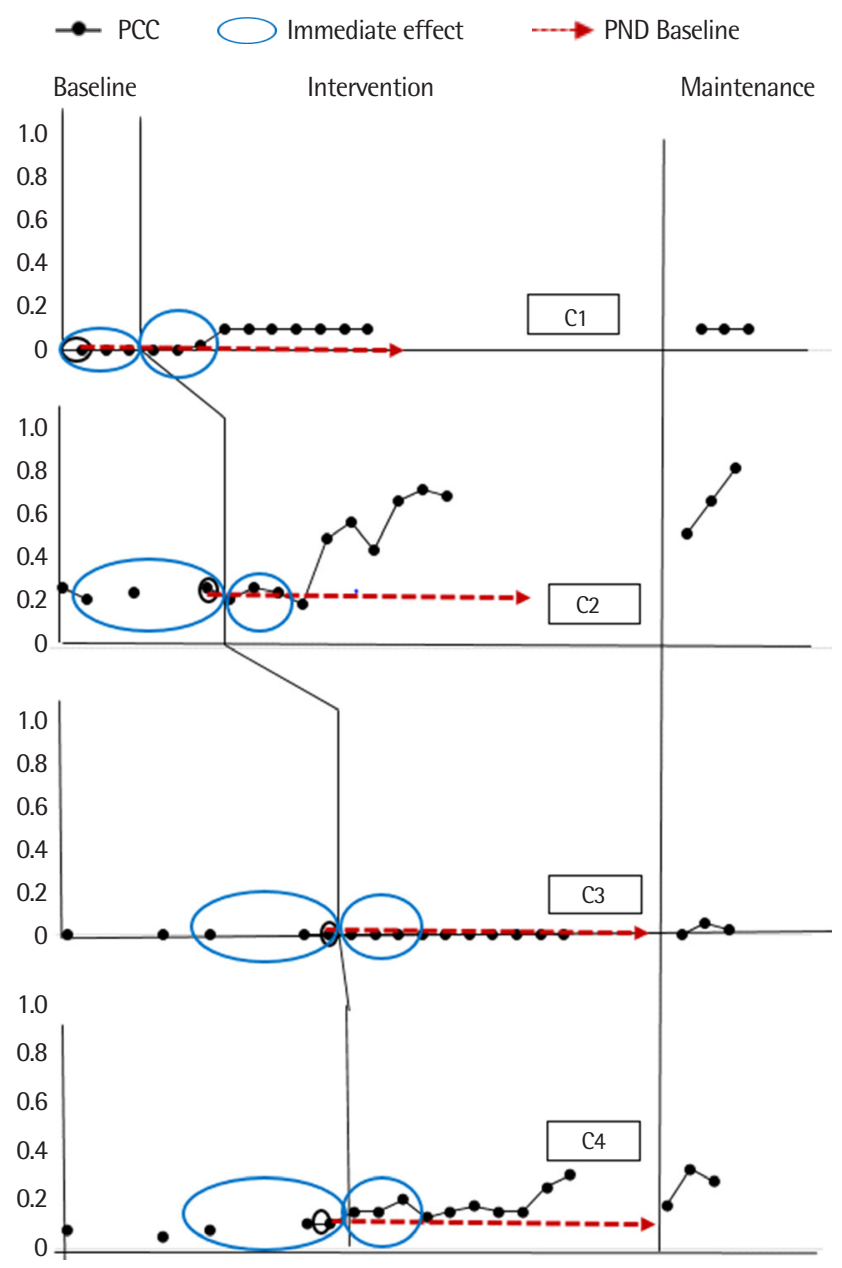

Figure 3. PWC data from participants C1-C4.

$\mathrm{PCC}=$ Percentage of Correct Consonant; $\mathrm{PND}=$ Percentage of Nonoverlapping Data.
로 변경되었다. 말소리 일관성 확립을 위한 핵심어휘접근법의 치료 목표는 성공적으로 달성되었음을 확인할 수 있었다. 다중감각접근 과 부모코칭을 보완하여 최상의 산출을 유도하고 연습과 일반화의 효과를 높이기 위해 프로그램을 보완하였으므로 비일관성뿐 아니 라 말소리의 정확성도 개선되었다.

최상의 산출을 위한 감각자극 방식 중 촉각단서는 유음, 치경파 찰음, 치경파열음, 비음(양순, 치경, 연구개)에서 사용하였고, 그 외 의 음소들은 청각.시각단서 제공만으로 정반응 산출이 가능하여 촉각단서는 제공하지 않았다. 탄설음과 치경마찰음은 모든 아동 이 최상의 산출 유도 후에도 정조음 산출이 어려워 가장 근접한 산 출방식으로 산출하도록 하였다. C3 아동과 $\mathrm{C} 4$ 아동은 치경파열음, 치경파찰음, 비음(양순, 치경, 연구개)에서 촉각단서를 제공받았고, $\mathrm{C} 1$ 아동과 $\mathrm{C} 2$ 아동은 설측유음과 치경파찰음에서 촉각단서를 제 공받았다. 4 명 중 3 명의 아동에서 정확성도 향상되는 결과를 보여 주었다.

치료효과는 개인차를 보였는데 특히, C4 아동은 말소리 일관성 확립뿐만 아니라 정확성에서도 가장 큰 치료효과를 보였다. 치료의 효과는 언어능력, 지능, 연령, 부모지원, 개인의 동기수준, 조음 문제 의 심각도에 따라 개별적 차이를 보이는데 기여할 수 있다. 이러한 요인들을 검토한 결과 특히 개별적으로 치료효과에 영향을 끼친 것 으로 보인 요인은 부모지원 요인과 아동의 동기수준이라고 판단되 었다. 부모지원을 가장 충실히 수행한 가정의 아동(C4)은 언어능 력, 지능수준 등이 네 아동 중 가장 낮았음에도 불구하고, 치료효 과가 빠르게 나타났다. C4 아동의 어머니는 참여 어머니들 중 유일 하게 치료 처음부터 마지막 회기까지 제공되는 부모코칭 자료의 절 
차대로 정확히 준수하여 지도하였으며, 가정지도 녹음파일을 매회 연구자에게 누리소통망(SNS)을 통해 전송하였다. 모든 참여 아동 의 어머니들에게 부모코칭을 통해 주 4 회의 가정지도를 시행하여, 그 내용을 전송하도록 하였는데, C4 아동의 어머니가 가장 충실하 게 제안한 가정지도의 회기를 모두 수행하고 전송하였고, 이 아동 의 말소리 비일관성 변화를 확인한 측정에서 PND 비율이 $100 \%$ 로 가장 높은 치료 효과를 나타냈다. C4 아동은 다른 참여 아동들보 다 낮은 지능수준과 언어능력을 가지고 있었을 뿐만 아니라, 과제 를 수행하는 동안 주의력 시간이 매우 짧았으며, 수업 시간에 엄마 가 보고 싶다고 울거나, 치료 내용과 상관없는 부수적인 이야기를 시도하는 등 수업의 흐름을 방해하는 여러 가지 행동 양식을 나타 내어 치료 시간 동안 목표단어를 산출할 기회가 현저하게 줄어들었 다. 이와 같이 짧은 주의력 및 수업의 흐름을 방해하는 여러 요인들 이 있었음에도 불구하고 높은 치료효과를 보였는데, 이는 지속적 이고 일관된 가정지도가 $\mathrm{C} 4$ 아동의 치료효과에 영향을 미쳤을 것 으로 보인다. 반면, 치료 초-중반 동안 가정에서 연습을 거부한다는 이유로 부모지원이 적절하게 제공되지 않았던 아동(C2)의 경우는 지속적인 부모코칭 후 가정지도가 제대로 진행되기 시작한 치료 후 반에서야 말소리 비일관성의 치료효과를 보였다. 이는 말소리 일관 성 확립이 목표인 핵심어휘접근법은 일상적인 가정에서의 연습 여 하에 따라 효과 차이가 있다고 Broomfiled와 Dodd (2005)의 조언 과 일치하였다. 그러나 동기수준이 높은 C2 아동은 지시 없이도 치 료시간 외 일반화 상황에서 다중감각자극 방법을 스스로 적용하 여 계속 연습하더니 빠르게 진전되고 잘 유지되었다.

$\mathrm{C} 3$ 아동을 제외한 모든 참여 아동들은 말소리 비일관성에서 나 타낸 감소효과와 비슷한 PND 비율로 PCC가 변화되는 효과를 보 였다. C3 아동은 치료기간 동안 발달적 오류패턴으로 변경된 최상 의 산출 방법으로 일관되게 유지할 수 있었다. C3의 정확성은 개선 되지 못했지만 비일관성은 개선된 것이다.

핵심어휘접근법의 치료효과를 확인한 기존의 선행연구들의 대 부분은 연령에 적절한 지능을 가진 아동들로 통제하여 실시하였 고(Holm \& Dodd, 1999), 지적장애를 동반한 아동에 대한 치료효 과를 확인하지는 않았으나, Herman 등(2015)의 연구는 언어 문제 를 동반한 아동에게 효과적인 것으로 확인하였다. 본 연구의 대상 아동들 중에서 사전에 실시한 검사에서 비언어성지능이 경계선급 이고 낮은 어휘수준을 보였던 두 아동의 경우에도 말소리 비일관성 이 유의하게 감소된 것을 확인할 수 있었다.

본 연구에서 핵심어휘접근법을 기본 프로그램으로 다중감각접 근법과 부모코칭 요소를 도입한 치료효과는 비일관성 감소에 매우 긍정적인 것으로 나타났으며, 정확성 향상에도 어느 정도 효과적이
었다. 이런 치료효과는 아래와 같은 몇 가지 요인들이 기여한 것으 로 사료된다. 첫째, 일상에서 자주 사용하는 고빈도 어휘를 목표로 하여 상황 일반화 환경에서도 최상의 산출 방법으로 산출하여 명 료도를 높일 수 있었다. 본 연구의 핵심어휘 확장 프로그램은 비일 관성 말소리장애 아동의 말소리 일관성 확립을 위해 개발되었고, 고빈도 어휘를 목표로 하는 핵심어휘접근법을 주요 접근법으로 사 용하였기 때문에, 고빈도 어휘를 사용한 것이다. 아동이 가정과 어 린이집에서 자주 사용하는 단어들을 동일한 방식으로 사용하게 되면서 상황 일반화를 극대화할 수 있었다. 치료기간 동안 확립된 말소리 일관성은 치료 종료 후 유지기간 동안에도 지속되었다. 둘 째, 치료 과정에서 아동이 목표단어와 음운적으로 가장 근접한 방 식으로 산출할 수 있도록 돕기 위해 강조한 ‘최상의 산출’ 방법은 말 소리 일관성 확립뿐만 아니라 오류패턴의 변화를 가져온 것으로 보 인다. 최상의 산출을 극대화하기 위해 핵심어휘접근법과 다중감각 접근법을 동시에 적용하여 최상의 조음조건으로 산출하도록 하였 기 때문에 ‘최상의 산출’이 더 촉진되어 정조음 산출 또는 발달적 오류패턴으로 변화된 것이다. 이러한 과정을 통해 말소리 일관성 확립뿐만 아니라, 정확성이 향상되는 효과를 보인 것으로 판단된 다. 셋째, 최상의 산출 방법대로 반복연습(Drill)을 사용한 것이 목 표한 음운체계로의 자동적 산출을 도와 일관된 단어산출을 촉진 한 것으로 보인다. 넷째, 치료사와 부모가 동일한 방법으로 일관된 산출에 대해서 지속적인 모니터링을 실시한 것이 촉진요인이 되었 다. 마지막으로, 부모코칭을 제공하여 가정에서 매일 일정한 시간 동안 치료실과 동일한 반복연습이 수행되어 긍정적인 치료효과를 나타낸 것으로 보인다.

본 연구의 제한점 및 후속연구를 위한 제언은 다음과 같다. 첫째, 본 연구의 핵심어휘 확장 프로그램은 말소리 일관성을 목표로 두 는 핵심어휘접근법을 주요 접근법으로 하여 말소리 일관성 산출을 통해 단어의 표상을 갖도록 하고, 명료도를 향상시키는 것을 목표 로 하였다. 핵심어접근법의 주요 목표는 말소리 일관성 확립이며, 치료 이후에 동반된 음운 정확성은 최상의 산출로 인한 부수적인 결과물이므로, 일관성 확립 치료 이후에 남아있는 음운오류패턴 은 상위음운접근법 또는 최소대립접근법 등 음운치료접근법을 적 용하여 변경하고 정확성을 향상시킬 필요가 있다. 이에 본 연구결 과, 말소리 일관성을 확립한 네 명의 대상 아동은 다음 단계의 정확 성 향상 프로그램을 개발 적용하고, 객관적인 효과를 검증할 필요 가 있다. 둘째, 본 연구에서 사용된 치료스타일은 목표단어를 매일 반복해야 하는 비일관성 말소리장애 아동들에게 효과적인 방법이 었으나, 일부 주의력이 부족하거나 동기가 적은 나이가 어린 아동 들이 보다 즐겁게 수행할 수 있는 방법의 모색이 필요하겠다. 셋째, 
부모코칭을 제공한 이후에 실제 부모지원 정도에 따라 효과 차이 를 보이는 것으로 여겨졌으나, 부모지원의 질적, 양적 차이를 객관 적 지표를 사용하여 확인하지 못하였다. 추후 연구에서는 부모코 칭을 통한 부모지원의 효과를 보다 통제된 조건에서 입증하는 연 구가 필요하겠다. 넷째, 본 연구의 프로그램은 모두 부모코칭을 통 한 부모지원을 병행하였다. 부모지원의 투입 정도를 최소화하기 위 해 모든 참가자의 어머니들에게 동일한 치료 절차에 따른 부모코칭 을 제공하였다. 치료 전과 치료기간 동안에 정해진 단계에 따라 부 모코칭을 순차적으로 제공하였고, 주당 연습 횟수, 1 일당 연습 시 간, 장소, 연습장소의 환경 등을 특정하여 안내하였다. 그리고 가정 에서의 연습 내용을 녹음하여 SNS를 통해 전달받고 피드백을 제 공하였다. 그러나 말 · 언어능력, 함께 보내는 시간, 치료 참여 동기 수준 등에 따라 부모지원을 수행하는 정도의 차이가 크게 나타났 다. 이와 같이 부모지원을 적극적으로 제공하지 못하는 가정의 아 동들도 가정에서 최소한의 부모지원으로도 연습할 수 있는 대체수 단을 개발할 필요가 있다. 다섯째, 본 연구에서 경계선급으로 낮은 지능 문제를 보인 두 명의 아동은 말소리 일관성과 정확성 모두에 서 치료 효과를 보였다. 핵심어휘접근이 지적장애를 동반한 비일관 성 말소리장애 아동에게도 효과가 있는지 확인하기 위해서는 보다 많은 지적장애를 동반한 말소리장애 아동을 확보해서 그 효과를 확인하는 것이 필요하겠다. 마지막으로, 말소리 일관성 확립 이후 에 어휘력 발달과 의사소통능력에 미치는 영향을 확인해 볼 필요 가 있겠다. 아동의 일관된 단어산출은 더 큰 범위의 어휘목록을 만 들기 때문에(Strokel \& Morrisette, 2002), 말소리 일관성이 확립되 면 산출 어휘의 수가 확장될 수 있다. 실제로 본 연구의 네 아동은 프로그램 전후에 실시한 어휘력 검사에서 상당한 향상을 보여주었 고, 일상에서의 의사소통능력도 크게 향상되었다. 향후 연구에서 는 말소리 일관성이 확립된 아동을 대상으로 어휘력과 의사소통능 력에서의 향상 효과를 확인하는 연구도 필요하겠다.

\section{REFERENCES}

Bradford, A. (1996). Subgroups of children with developmental speech disorder: identification and remediation (Doctoral dissertation), University of Queensland, Brisbane, Australia.

Broomfield, J., \& Dodd, B. (2005). Clinical effectiveness. London: Whurr.

Crosbie, S., Holm, A., \& Dodd, B. (2005). Intervention for children with severe speech disorder: a comparison of two approaches. International Journal of Language and Communication Disorders, 40(4), 467-91.

Dodd, B. (2005). Differential diagnosis and treatment of children with speech disorder (2nd ed.). London: Whurr.

Dodd, B., \& Bradford, A. (2000). A comparison of three therapy methods for children with different types of developmental phonological disorders. International Journal of Language and Communication Disorders, 35(2), 189209.

Dodd, B., Crosbie, S., Zhu, H., Holm, A., \& Ozanne, A. (2002). The diagnostic evaluation of articulation and phonology. London: Pearson PsychCorp.

Dodd, B., \& Iacono, T. (1989). Phonological disorders in children: changes in phonological process use during treatment. British Journal of Communication Disorders, 24(3), 333-51.

Dodd, B., Leahy J., \& Hambly, G. (1989). Phonological disorders in children: underlying cognitive deficits. British Journal of Developmental Psychology, 7(1), 55-71.

Dodd, B., Zhu, H., Crosbie, S., Holm, A., \& Ozanne, A. (2006). Diagnostic Evaluation of Articulation and Phonology (DEAP). San Antonio, TX: PsychCorp of Harcourt Assessment.

Elbert, M., Powell, T., \& Swartzlander, P. (1991). Toward a technology of generation: how many exemplars are sufficient?. Journal of Speech and Hearing Research, 34(1), 81-87.

Ferguson, C., \& Farwell, C. (1975). Words and sounds in early language acquisition. Language, 51(2), 39-49.

Forrest, K. (2003). Diagnostic criteria of developmental apraxia of speech used by clinical speech-language pathologists. American Journal of SpeechLanguage Pathology, 12(3), 376-380.

Gunther, T., \& Hautvast, S. (2010). Addition of contingency management to increase home practice in young children with a speech sound disorder. International Journal of Language and Communication Disorders, 45(3), 345-353.

Ha, S., \& Seo, D. (2019). Articulatory consistency for differential diagnosis of speech sound disorders. Communication Sciences \& Disorders, 24(4), 10151025.

Hayden, D. A. (2004). PROMPT: A tactually grounded treatment approach to speech production disorders. In I. Stockman (Ed.), Movement and action in learning and development: clinical implications for pervasive developmental disorders (pp. 255-297). San Diego. CA: Elsevier-Academic Press.

Herman, R., Ford, K., Thomas., J., Oyebade, N., Bennett, D., \& Dodd, B. (2015). Evaluation of core vocabulary therapy for deaf children: Four treatment case studies. Child Language Teaching and Therapy, 31(2), 221-235.

Hesketh, A. C., Nightingale, C., \& Hall, R. (2000). Phonological awareness therapy and articulatory training approaches for children with phonologi- 
cal disorders: a comparative outcome study. International Journal of Language and Communication Disorders, 35(3), 337-354.

Holm, A., \& Dodd, B. (1999). An intervention case study of a bilingual child with phonological disorder. Child Language Teaching and Therapy, 15(2), $139-158$.

Ingram, D. (2002). The measurement of whole-word productions. Journal of Child Language, 29(4), 713-733.

Kim, M., Pae, S., \& Park, C. (2007). Assessment of Phonology \& Articulation for Children (APAC). Incheon: Hube R \& C.

Kim, M., Kim. S., Ha, J., \& Ha, S. (2015). A survey of co-morbidity and speechlanguage characteristics in speech sound disorders. Communication Sciences \& Disorders, 20(3), 446-455.

Kim, Y., Hong, G., Kim, K., Jang, H., \& Lee, J. (2009). Receptive \& Expressive Vocabulary Test (REVT). Seoul: Seoul Community Rehabilitation Center.

Ko, Y., Seo, E., Oh, K., \& Kim, S. (2017). Comorbidity of language impairment according to gender, age, and severity in children with speech sound disorders. Korean Speech-Language \& Hearing Association, 26(4), 99-109.

Kratochwill, T. R., Hitchcock, J., Horner, R. H., Levin, J. R., Odom, S. L., Rindskopf, D. M., \& Shadish, W. R. (2010). Single-case designs technical documentation. Retrieved from What Works Clearing-house website: http:// ies.ed.gov/ncee/wwc/pdf/wwc_scd.pdf.

Lancaster, G., Keusch, S., Levin, A., Pring, T., \& Martin, S. (2010). Treating children with phonological problems: does an eclectic approach to therapy work?. International Journal of Language and Communication Disorders, 45(2), 174-181.

Lawrence, D., Shriberg, L., Thomas, F., Campbell, R., Heather, B., Karlsson, H., ..., \& Connie, J. (2003). A diagnostic marker for childhood apraxia of speech: the lexical stress ratio. Clinical Linguistics and Phonetics, 17(7), 549574.

Lee, S. A. S. (2018). The treatment efficacy of multiple opposition phonological approach via telepractice for two children with severe phonological disorders in rural areas of West Texas in the USA. Child Language Teaching and Therapy, 34(1), 63-78.

Lewis, B. A., Frebairn, L., Tag, J., Ciesla, A. A., Iyenger, S. K., Stein, C. M., \& Taylr, H. G. (2015). Adolescent outcomes of children with early speech sound disorders with and without language impairment. American Journal of Speech-Language Pathology, 24(2), 150-163.

Lewis, B. A., Short, E. J., Iyenger, S. K., Taylor, H. G., Freebairn, L., Tag, J., ..., \& Stein, C. M. (2012). Speech-sound disorders and attention-deficit/hyperactivity disorder symptom. Topics in Language Disorders, 32(3), 247 -
263.

Lim, H. (2004). Korean Version of Raven CPM Intelligence Test for Infants. Seoul: Korea Guidance.

McIntosh, B., \& Dodd, B. (2008). Evaluation of core vocabulary intervention for treatment of inconsistent phonological disorder: three treatment case studies. Child Language Teaching and Therapy, 24(3), 307-327.

Passy, J. (1990). Cued articulation. Camberwell, Victoria, Australia: Australian Council for Educational Research.

Paul, P. (1993). Patterns of development in late talkers: preschool years. Communication Disorders Quarterly, 15(1), 7-14.

Pieretti, R. A., Kaul, S. D., Zarchy, R. M., \& O’Hanlon, L. M. (2015). Using a multimodal approach to facilitate articulation, phonemic awareness, and literacy in young children. Communication Disorders Quarterly, 36(3), 131-141.

Rogers, S. J., Hayden, D., Hepburn, S., Charlifue-Smith, R., Hall, T., \& Hayes, A. (2006). Teaching young nonverbal children with autism useful speech: a pilot study of the Denver Model and PROMPT interventions. Journal of Autism and Developmental Disorders, 36(8), 1007-1024.

Schmidt, R., \& Lee, T. (1999). Motor control and learning: a behavioral emphasis. Champaign, IL: Human Kinetics.

Shriberg, L. D., \& Austin, D. (1998). Comorbidity of speech-language disorder: implications for a phenotype marker for speech delay. In R. Paul (Ed.), The speech-language connection (pp. 73-117). Baltimore: Paul H. Brookes.

Shriberg, L., Austin, D., Lewis, B. A., McSweeny, J. L., \& Wilson, D. L. (1997). The speech disorders classification system (SDCS): extensions and lifespan reference data. Journal of Language and Hearing Research, 40(4), 708722.

Shriberg, L. D., Tomblin, J. B., \& McSweeny, J. L. (1999). Prevalence of speech delay in 6-year-old children and comorbidity with language impairment. Journal of Speech, Language, and Hearing Research, 42, 1461-1481.

Shriberg, L. D., Strand, E. A., Fourakis, M., Jakielski, K. J., Hall, S. D., Karlsson, H. B., ..., \& Wilson, D. L. (2017). A diagnostic marker to discriminate childhood apraxia of speech from speech delay: III. Theoretical coherence of the pause marker with speech processing deficits in childhood apraxia of speech. Journal of Speech Language and Hearing Research, 60(4), 11351152.

Square, P. A., Namasivayam, A. K., Bose, A., Goshulak, D., \& Hayden, D. (2014). Multi-sensory treatment for children with developmental motor speech disorders. International Journal of Language and Communication Disorders, 49(5), 527-542. 
Square, P. A., Goshulak, D., Bose, A., \& Hayden, D. A. (2000). The effects of articulatory subsystem treatment for developmental neuromotor speech disorders. Paper presented at the Tenth Biennial Conference on Motor Speech Disorders and Speech Motor Control, San Antonio, TX.

Storkel, H., \& Morrisette, M. (2002). The lexicon and phonology: interaction in language acquisition. Language, Speech, and Hearing Services in Schools, 33(1), 24-37.

Weiss, C., Gordon, M., \& Lillywhite, H. (1987). Clinical management of articulatory and phonological disorders. Baltimore: Williams \& Wilkins. 
Appendix 1. Integrated Treatment Program Model

\begin{tabular}{|c|c|c|c|}
\hline 목 적 & \multicolumn{3}{|c|}{ - 아동에게 음운을 어떻게 구성하는지 가르치는 데 목적이 있다. } \\
\hline 장기목표 & \multicolumn{3}{|c|}{ - 목표 50개 단어를 최상의 산출(정조음 또는 발달오류)방법으로 일관성 있게 산출하기 } \\
\hline 단기목표 & \multicolumn{3}{|c|}{$\begin{array}{l}\text { - 목표 1. 음운체계와 음운목록을 기반으로 각 목표의 적절한 산출 방법 인식하기 } \\
\text { - 목표 2. 아동이 확립한 최상의 산출을 일관되게 지속적으로 사용하기 } \\
\text { * 최상의 산출: 목표 낱말을 음운적으로 가장 비슷하게 산출할 수 있는 최적의 산출 방법; 정조음 산출 또는 발달적 오류로 산출하기 }\end{array}$} \\
\hline $\begin{array}{l}\text { 제공주기 } \\
\text { 및 제공 } \\
\text { 시간 }\end{array}$ & \multicolumn{3}{|c|}{$\begin{array}{l}\text { - 주 2회/ 회당 } 40 \text { 분 / } 10 \text { 주간 } \\
\text { - 첫 4회는 TACTILE PROMPT의 단계(Surface PROMPT, Air PROMPT) 중 필요한 단계 } \\
\text { - 3주차부터 } 10 \text { 분의 추가 시간은 PROMPT 감각 자극을 추가 실시에 필요한 소요시간 } \\
\text { - PROMPT 자극 시 아동이 산출 가능한 최상의 산출을 위한 음소 자극 제시 } \\
\text { ※ 목표 기준을 달성하지 못한 경우에도 최대 } 16 \text { 시간 } 30 \text { 분을 초과하면 안 됨. }\end{array}$} \\
\hline \multirow[t]{5}{*}{ 제공절차 } & 1단계 & $\begin{array}{l}\text { 〈주간 치료 목표단어 선정〉 } \\
\text { - 매주 첫 회기 실시 } \\
\text { - } 50 \text { 개의 목표단어 중 } 10 \text { 개 단어 선정하기 } \\
\text { - 매주 목표단어 선정 시 지난주에 최상의 단어산출을 확립하지 못한 단어를 } \\
\quad \text { 목표단어에 포함하기: 매주 } 10 \text { 개 단어 선정 }\end{array}$ & - 무작위로 목표 그림 뽑기 \\
\hline & 2단계 & $\begin{array}{l}\text { 〈최상의 산출체계 구축〉 } \\
\text { - 매주 첫 회기 실시: 선정된 단어 가르치기 } \\
\text { - 선정된 단어를 아동이 산출할 수 있는 최상의 산출 방법으로 가르치기 } \\
\text { - 매주 첫 회기는 일관성 확립을 위한 반복 연습이 아닌 목표단어가 최상의 산출 } \\
\text { 이 될 수 있도록 돕는 연습만 실시 } \\
\text { (1) 아동이 산출 가능한 최상의 산출 방법 찾기 } \\
\text { - 청각, 촉각, 시각자극을 사용하여 찾기 } \\
\text { (2) 다중감각접근법의 감각자극을 사용하여 음절분절, 모방 및 조음방법을 소리 } \\
\quad \text { 별로 가르치기(Passy, 1990) }\end{array}$ & $\begin{array}{l}\text { 〈치료 스타일〉 } \\
\text { - Drill 사용 } \\
\text { 〈부모코칭> } \\
\text { - 최상의 산출 방법이 확립되어 치료실 회기에서 } \\
\text { 3회 연속 최상의 음으로 산출 가능한 단어들을 } \\
\text { 과제로 제시 }\end{array}$ \\
\hline & 3단계 & $\begin{array}{l}\text { 〈목표단어 반복 연습> } \\
\text { - 매주 두 번째 회기 실시 } \\
\text { - 반복 연습을 위해 게임 활동 사용 } \\
\text { - 초기 활동: 그림 명명하기 활동 일관성이 확립될 때까지 } 5 \text { 회 연속 산출 연습 } \\
\text { - 목표한 } 10 \text { 단어를 } 5 \text { 회 연속하여 일관성이 확립되면 ‘4단계' 운반구 연습 실시 } \\
\text { - 목표 낱말은 지난주 } 5 \text { 회 연속 일관성을 확립하지 못한 단어들까지 포함하면 } \\
\text { 10개를 초과할 수 있음. } \\
\text { - 모든 목표단어가 최상의 산출체계를 구축하면 이후 매주 첫 회기에도 목표단어 } \\
\text { 반복연습 실시 }\end{array}$ & $\begin{array}{l}\text { 〈치료 스타일〉 } \\
\text { - Drill 사용 } \\
\text { - 30분간 목표단어를 최소 100회 이상 반응으로 산 } \\
\text { 출하도록 함(Elbert, Powell, \& Swartzlander, } \\
\text { 1991) } \\
\text { <부모코칭〉 } \\
\text { - 다음 회기까지 목표단어를 매일 20분간 연습하여 } \\
\text { 연습과정을 녹음하도록 함(각 단어를 연속 } 5 \text { 회 } \\
\text { 이상 산출하도록 지도) }\end{array}$ \\
\hline & 4단계 & $\begin{array}{l}\text { 〈운반구를 활용한 목표단어 연습> } \\
\text { - 매주 두 번째 회기 실시 } \\
\text { - } 2 \text { 차 활동: 운반구 연습 } \\
\text { - 초기 활동에서 } 5 \text { 회 이상 일관성을 확립한 단어들로 구성 } \\
\text { - 운반구 활동에서는 연속하여 같은 단어를 연습하지 않고, 목표단어들이 포함된 } \\
\text { 문장을 순차적으로 각 } 1 \text { 회씩 연습한 후, 목표단어 모두 } 5 \text { 번째까지 순서가 마무 } \\
\text { 리되면 종료 } \\
\text { - 운반구 활동 중 목표단어의 최상의 산출이 나타나지 않을 경우, 잠시 운반구 활 } \\
\text { 동을 중단하고 해당 단어를 연속 반복 연습 } \rightarrow \text { 연습한 단어가 일관성이 확립되면 } \\
\text { 다시 운반구 활동 실시 }\end{array}$ & $\begin{array}{l}\text { 〈치료 스타일〉 } \\
\text { - Drill/Drill Play 사용 } \\
\text { 〈부모코칭〉 } \\
\text { - 운반구 활동을 매일 20분간 연습하여 연습과정을 } \\
\text { 녹음하도록 함 }\end{array}$ \\
\hline & 5단계 & $\begin{array}{l}\text { 〈목표단어의 일반화 사용〉 } \\
\text { - 마지막 주간 실시 } \\
\text { - 일상생활의 의사소통 상황에서 피드백 제공 } \\
\text { - 반복 연습한 목표단어의 운반구 연습 후 일관성 확립 시 사용 } \\
\text { - 스크립트 문맥 사용하기, 이야기 재구성, 역할놀이 상황에서 목표단어의 일관 } \\
\text { 성을 확인하고 최상의 산출이 나타나지 않는 경우 피드백 제공 }\end{array}$ & \begin{tabular}{|l} 
〈치료 스타일〉 \\
구조적 놀이 \\
〈부모코칭> \\
- 스크립트 문맥, 이야기 재구성, 역할놀이 상황을 \\
$\quad$ 제시한 후, 활동하는 동안 일관성을 확인하고 \\
피드백을 주도록 지도(20분간 녹음하도록 함)
\end{tabular} \\
\hline
\end{tabular}




\section{국문초록}

\section{비일관성 말소리장애아동을 위한 핵심어휘 확장 프로그램의 효과 \\ 고유경 $\cdot$ 김수진 \\ '바른소리언어학습연구소, ${ }^{2}$ 나사렛대학교 언어치료학과}

배경 및 목적: 본 연구의 목적은 말소리 일관성 확립을 위한 핵심어휘 확장 프로그램이 비일관성 말소리장애아동의 말소리 비일관성과 정확성에 미치는 효과를 확인하는 것이다. 방법: 말소리 비일관성, 음운오류패턴 및 조음문제를 동시에 보이는 3-5세의 비일관성 말소 리장애아동 4 명이 참여하였다. 본 연구의 프로그램은 핵심어휘접근법과 다중감각접근법을 사용하였고, 부모지원을 동시에 제공하였 다. 실험설계는 중다기초선실험설계를 사용하였고, 각 3-5회의 기초선 평가, 10 회의 치료 평가 및 3 회의 유지 평가가 수행되었다. 종속 변 수의 데이터 분석, 평균, 경향선기울기, 표준편차, 치료의 즉각적인 효과 및 비중복정도(PND)의 비율을 분석하였다. 결과: 말소리 비일 관성이 감소되었고, $\mathrm{PCC}$ 와 $\mathrm{PWC}$ 이 향상되었다. 말소리 비일관성은 4 명의 참여아동 모두에서 치료효과를 보였고, 정확성은 3 명의 아 동에서 치료효과를 나타냈다. 논의 및 결론: 본 연구는 핵심어휘 확장 프로그램이 지적문제와 언어장애를 동반한 비일관성 말소리장 애아동의 말소리 비일관성 및 정확성에 대한 치료효과를 확인했다는 점에서 의의가 있다. 향후에는 말소리 일관성이 확립된 이후에 남 아있는 음운오류패턴의 제거를 위해 음운치료접근법을 적용하여 그 효과를 확인하는 연구가 필요하겠다.

핵심어: 말소리 비일관성, 핵심어휘접근법, 다중감각접근법, 비일관성 말소리장애

본 논문은 제1저자의 박사학위논문을 발췌 및 수정한 것임.

\section{참고문헌}

고유경, 서은영, 오경아, 김수진 (2017). 말소리장애아동의 성별, 연령별, 중증도에 따른 언어장애 동반비율. 언어치료연구, 26(4), 99-109. 김민정, 김수진, 하지완, 하승희 (2015). 말소리장애의 동반장애 유형 및 말-언어 특성에 관한 설문조사. Communication Sciences \& Disorders,

20(3), 446-455.

김민정, 배소영, 박창일 (2007). 아동용 발음평가. 인천: 휴브알앤씨.

김영태, 홍경훈, 김경희, 장혜성, 이주연 (2009). 수용·표현 어휘력 검사. 서울: 서울장애인종합복지관.

임호찬(2004). 한국판 Raven CPM 유아용 지능검사. 서울: 한국가이던스.

하승희, 서동기 (2019) 말소리장애 감별 진단을 위한 조음 일관성 연구. Communication Sciences \& Disorders, 24(4), 1015-1025.

\section{ORCID}

고유경(제1저자, 연구소장 https://orcid.org/0000-0003-3592-2147); 김수진(교신저자, 교수 https://orcid.org/0000-0002-0108-6198) 